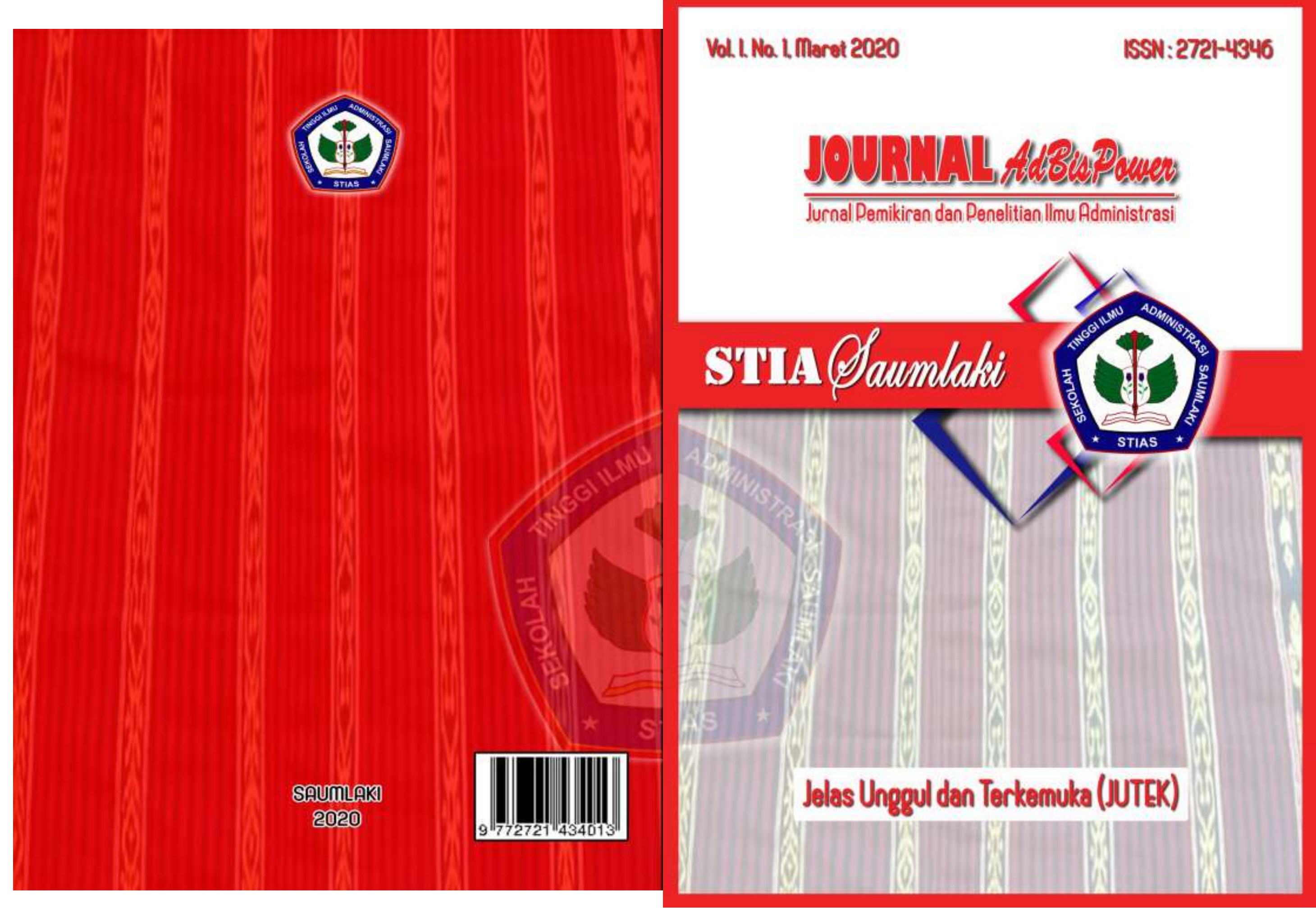




\title{
KINERJA APARATUR PEMERINTAH DESA DAN PELAYANAN KEPADA MASYARAKAT DI DESA MEYANO BAB KECAMATAN KORMOMOLIN KABUPATEN KEPULAUAN TANIMBAR
}

Oleh :

\author{
Kristhiana A. Laratmase \\ (Dosen STIA Saumlaki)
}

\begin{abstract}
ABSTRAK
Pelayanan aparatur pemerintah pada setiap jenjang pemerintahan dewasa ini belum makasimal untuk dilaksanakan sehingga berdapak dalam kehidupan masyarakat. Oleh karenanya penelitian ini dilakukan untuk mengetahui hubungan antara Kinerja Aparatur Pemerintah Desa dengan Pelayanan Kepada Masyarakat di Desa Meyano Bab Kecamatan Kormomolin Kabupaten Kepulauan Tanimbar. Pengumpulan data dilakukan dengan menggunakan kuesioner sebagai instrumen utama penelitan dengan sampel sebanyak 50 responden yang dianalisis dengan menggunakan rumus Korelasi Pearson Produck Moment dan uji signifikasinya dilakukan dengan mengunakan uji $\mathrm{t}(\mathrm{t}$-tes).

Hasil penelitian dengan menggunakan rumus Korelasi Pearson Product Moment diperoleh hasil nilai $\mathrm{r}=0,82$ yang menunjukan bahwa ada hubungan yang Sangat Kuat antara Kinerja Aparatur Pemerintah Desa dengan Peyananan Kepada Masyarakat pada interval 0,80 - 1,000. Sementara kontribusi variabel Kinerja Aparatur Pemerintah Desa terhadap variabel Peyananan Kepada Masyarakat sebesar 67\% sedangkan sisanya 33\% ditentukan oleh fakor lain yang tidak sempat diteliti oleh penulis, dan uji signifikansi dengan mengunakan formula uji t (t-test) pada taraf nyata signifikan $5 \%(0,05)$ uji dua arah dengan $\mathrm{dk}=\mathrm{n}-2(50-2=48)$ maka diperoleh nilai t-hitung sebesar 9,95 lebih besar dari nilai t-tabel 1,98 $(9,95>1,684)$, sehingga dapat dikatakan bahwa hipotesa Ha diterima sedangkan hipotesa $\mathrm{H}_{0}$ ditolak.
\end{abstract}

Kata Kunci; Kinerja dan Pelayanan Aparatur, Pemerintah Desa.

\section{ABSTRACT}

The services of government officials at every level of government today have not been maximally implemented so that they have an impact on people's lives. Therefore this research was conducted to determine the relationship between the performance of village government officials and services to the community in Meyano Bab Village, Kormomolin District, Tanimbar Islands Regency. The data were collected using a questionnaire as the main research instrument with a sample of 50 respondents who were analyzed using the Pearson Produck Moment Correlation formula and the significance test was carried out using the $t$ test (t-test.

The results of the study using the Pearson Product Moment Correlation formula obtained the results of the value of $r=0.82$ which indicates that there is a very strong relationship between the performance of the village government apparatus and the community belief in the interval 0.80 - 1,000. Meanwhile, the contribution of the Village Government Apparatus Performance variable to the Community Care variable was $67 \%$, while the remaining $33 \%$ was determined by other factors that were not researched by the author, and the significance test used the t-test formula (t-test) at a significant level of $5 \%(0.05)$ two-way test with $\mathrm{dk}=\mathrm{n}-2(50-2=48)$, then the $\mathrm{t}$-count value of 9.95 is greater than the t-table value of $1.98(9.95>1.684)$, so it can be It is said that the hypothesis $\mathrm{Ha}$ is accepted while the hypothesis Ho is rejected.

Keywords; Apparatus Performance and Services, Government Village. 


\section{PENDAHULUAN}

Gerakan Reformasi yang bergulir sejak tahun 1998 telah melahirkan rangkaian perubahan yang sangat signifikan dalam seluruh aspek kehidupan berbangsa dan bernegara, baik dibidang Politik danEkonomi, maupun HANKAM. Gerakan Reformasi dibidang politik telah merobah dan merombak praktek-praktek penyelenggaraan pemerintahan yang bersifat desentralistik yang demokratis dengan memberikan kebebasan kepada masyarakat guna menyampaikan pendapat tanpa ada tekanan darimanapun.

Tuntutan adanya demokratisasi dan desentralisasi dalam penyelenggaraan pemerintahan di tingkat lokal pun semakin tak terelakan lagi yang pada akhirnya menghasilkan perubahan yang sangat fundamental dalam tata pemerintahan daerah, dimana Undang-Undamg No 5 Tahun 1974 sebagai landasan regulasinya mengalami perubahan menjadi Undangundang No 22 Tahun 1999 yang telah direvisi menjadi Undang-undang No 32 Tahun 2004 yang terus mengalami perubahan dan penyempurnaan menjadi Undang-Undang nomor 23 tahun 2016 tentang pemerintah daerah (Alaslan, 2021: 1)

Jiwa dan semangat otonomi daerah itu terus menghasilkan rangkaian perubahan kemajuan dan keberhasilan di zaman reformasi saat ini, telah

mendoorong berbagai komponen otonomi daerah teristimewa aparatur pemerintah sampai ketingkat desa untuk mampu melaksanakan tugas pokok, fungsi dan tanggungjawabnya sebagai pelayan masyarakat. Selain itu juga Aparatur pemerintahan pada setiap tingkatan diharapkan mampu menjawab berbagai kebutuhan dan permasalahan yang semakin kompleks dihadapi oleh masyarakat.

$$
\text { Menurut Widodo, (2006:29), }
$$
pemerintah saat ini setidaknya berada dan berhadapan dengan beberapa masalah antara lain:

1. Lingkungan strategis yangsenantiasa berubah,

2. Pergeseran penyelenggaraan pembangunan masyarakat;

3. Kondisi masyarakat yang mengalami dinamika perubahan.

Menghadapi dinamika masyarakat sebagaimana disebutkan diatas, dituntut kemampuan aparat pemerintah desa yang professional dalam melaksanakan administrasi pemerintahan yang menjadi tugas pokok, fungsi serta kewenangan dan tanggung jawab yang diamanatkan oleh rakyat.

Undang-Undang Nomor 25 Tahun 2009 tentang Pelayanan Publik menyatakan bahwa dewasa ini 
penyelenggaraanpelayanan publik masih diperhadapkan padakondisi yang belum sesuai dengankebutuhan dan perubahan di berbagai bidangkehidupan bermasyarakat, berbangsa danbernegara. Hal tersebut bisa disebabkan olehketidaksiapan untuk menanggapi terjadinyatransformasi nilai yang berdimensi luas sertadampak berbagai masalah pembangunanyang kompleks.

$$
\text { Sementara itu, tatanan }
$$
barumasyarakat diperhadapkan pada harapan dan tantangan global yang dipicu oleh kemajuan di bidang ilmu pengetahuan, informasi,komunikasi, transportasi, investasi danperdagangan. Kondisi seperti ini perludisikapi secara bijak melalui langkah-langkah kegiatan yang terus menerus dan berkesinambungan dilakukan di berbagai aspekpembangunan. Untuk itu diperlukankonsepsi tentang pelayanan publik yangberisi nilai, persepsi, dan acuan perilakuyang mampu mewujudkan hak asasimanusia sebagaimana yang diamanatkanoleh UUD 1945 dapat diterapkan sehinggamasyarakat memperoleh pelayanan sesuaidengan harapan dan cita-cita tujuan nasional(UU No.25 Tahun 2009).

Kemampuan Pemerintah Desa dalam pelaksanaan tugas dan fungsi administrasi di Desa Meyano Bab Kecamatan Kormomolin Kabupaten
Kepulauan Tanimbar harus memiliki kemampuan dan pengalaman agar bersikap demokratis, responsive dan adaptif dalam melaksanakan apa yang menjadi tugas pokok, fungsi dan tanggung jawab utama yang diamanatkan kepadanya. Terutama dalam menyikapi perubahan lingkungan, tuntutan, aspirasi, guna menciptakan kondisi yang memungkinkan setiap anggota masyarakat mengembangkan kemampuan dan kreatiifitas demi mencapai tujuan bersama menghadapi kondisi sebagaimana yang telah digambarkan tersebut. Konsep inilah yang kemudian dpertegas oleh Alaslan (2021: 3) sebagai sebuah sosial capital dengan adanya rasa solidaritas dan resposivitas pemerintah untuk pemenuhan kebutuhan dan kepentingan masyarakat dalam mewujudkan kesejahteraan bersama.

Pemerintah desa Meyano Bab Kecamatan Kormomolin Kaupaten Maluku Tenggara Barat harus senantiasa meningkatkan kemampuan dan pengalaman dalam melaksanakan tugas pokok, fungsi, kewenangan dan tanggung jawab, administrasi pemerintahan dalam memberikan pelayanan public.

Data observasi peneliti menunjukkan bahwa kinerja Pemerintah Desa Meyano Bab dalam pelayanan publik masih memiliki banyak kelemahan, baik pada aspek efektivitas pelayanan, 
efisiensi pelayanan, responsivitas pelayanan, maupun kualitas layanan. Kelemahan pada aspek efektivitas dapat dindikasikan oleh ketidakmampuan pemerintah desa dalam mengembangkan dan melaksanakan program pelayanan kepada masyarakat yang menjadi ruang lingkup tugas pemerintah desa. Kelemahan kinerja pada aspek efisiensi dapat diindikasikan ketidakmampuan pemerintah desa melaksanakan pelayanan kepada masyarakat secara cepat, tepat, dan mudah baik dari segiwaktu, biaya maupun prosedur pelayanan.

Kelemahan kinerja pada aspek responsivitas dapat diindikasikan oleh ketidakmampuan pemerintah desa dalam menanggapi atau memenuhi harapan atau tuntutan masyarakat secara cepat dan tepat. Sedangkan kelemahan kinerja pada aspek kualitas layanan dapat diindikasikan oleh ketidakmampuan pmerintah desa dalam melaksanakan pelayanan yang memuaskana masyarakat mengenai prosedur pelayanan, persyaratan pelayanan, teknik dan administrasi pelayanan, tanggungjawab aparat pelayanan dan waktu penyelesaian pelayanan. Hal inilah yang menjadi dasar dilakukknya penelitian tentang Kinerja Aparatur Pemerintah Desa dan Pelayanan Kepada Masyarakat di Desa Meyano Bab Kecamatan Kormomolin Kabupaten Kepulauan Tanimbar.

\section{LANDASAN TEORI}

\section{Konsep Kinerja}

Secara etimologi, kata kinerja berarti suatu yang hendak dicapai, prestasi yang diperlihatkan, kemampuan kerja. Dalam Dictionary Contemporary English Indonesia, istilah kinerja digunakan bila seseorang menjalankan suatu proses dengan terampil sesuai dengan prosedur dan ketentuan yang ada. Kinerja dapat dilihat dari berbagai sudut pandang tergantung kepada tujuan masing-masing organisasi misalnya untuk profit ataukah untuk customer satisfaction, dan juga tergantung pada bentuk organisasi itu sendiri (misalnya organisasi publik, swasta, bisnis, sosial dan keagamaan). Lebih lanjut terkait hal ini, Samsudin (2005:159) berpendapat bahwa Kinerja adalah tingkat pelaksanaan tugas yang dapat dicapai seseorang, unit atau divisi dengan menggunakan kemampuan yang ada dan batasan-batasan yang telah ditetapkan untuk mencapai tujuan organisasi/perusahaan.

Adapun definisi kinerja menurut Dharma (1991:1) kinerja atau prestasi kerja adalah suatu yang dihasilkan atau produk atau jasa yang dihasilkan atau yang diberikan oleh seseorang atau sekelompok orang”. Untuk dapat melakukan penilaian terhadap efektivitas atau kinerja ini, Gibson dkk (1990:11) 
menyatakan bahwa "Penilaian yang kita buat sesuai dengan prestasi individu, kelompok dan organisasi makin dekat mereka terhadap prestasi yang diharapkan makin efektif kita menilai mereka". Indikator yang digunakan untuk menilai kinerja organisasi, yang terdiri atas beberapa faktor berikut :

a. Tangibles atau ketampakan fisik, artinya ketampakan fisik dari gedung, peralatan, pegawai, dan fasilitasfasilitas lain yang dimiliki oleh providers.

b. Reliability atau reabilitas adalah kemampuan untuk menyelenggarakan pelayanan yang dijanjikan secara akurat.

c. Responsiveness atau responsivitas adalah kerelaan untuk menolong customersdan menyelenggarakan pelayanan secara ikhlas.

d. Assurance atau kepastian adalah pengetahuan dan kesopanan para pekerja dan kemampuan mereka dalam memberikan kepercayaan kepada customers.

e. Emphaty adalah perlakuan atau perhatian pribadi yang diberikan oleh providerskepada customers.

$$
\text { Agus Dwiyanto }
$$
mengemukakan bahwa untuk menilai kinerja organisasi dapat digunakan beberapa kriteria sebagai pedoman penilaian kinerjaorganisasi pelayanan publik, antara lain :

a. Efisiensi

Efisiensi menyangkut pertimbangan tentang keberhasilanorganisasi pelayanan publik mendapatkan laba, memanfaatkan faktor-faktor produksi serta pertimmbangan yang berasal dari rasionalitas ekonomis.

\section{b. Efektivitas}

Apakah tujuan dari didirikannya organisasi pelayanan publik tercapai Hal tersebut erat kaitannya dengan rasionalitas teknis, nilai, misi, tujuan organisasi, serta fungsi agen pembangunan.

c. Keadilan

Keadilan mempertanyakan distribusi dan alokasi layanan yang diselenggarakan oleh organisasi pelayanan publik. Kriteria ini erat kaitannya dengan konsep ketercukupan atau kepantasan.

d. Daya Tanggap(Responsivitas)

Berlainan dengan bisnis yang dilaksanakan oleh perusahaan swasta, organisasi pelayanan public merupakan bagian dari daya tanggap negara atau pemerintahakan kebutuhan vital masyarakat. 
Agus Dwiyanto (2006:50) mengukur kinerja birokrasi publik berdasar adanya indikator yang secara lebih lanjut dijelaskan sebagai berikut :

a. Produktivitas

Konsep produktivitas tidak hanya mengukur tingkat efisiensi, tetapi juga efektivitas pelayanan. Produktivitas pada umumnya dipahami sebagai rasio antara input dengan output.

b. Kualitas Layanan

Isu mengenai kualitas layanan cenderung semakin menjadi penting dalam menjelaskan kinerja organisasi pelayanan publik. Banyak pandangan negatif yang terbentuk mengenai organisasi publik muncul karena ketidakpuasan masyarakat terhadap kualitas layanan yang diterima dari organisasi publik.

c. Responsivitas

Responsivitas adalah kemampuan organisasi untuk mengenali kebutuhan masyarakat, menyusun agenda dan prioritas pelayanan, mengembangkan programprogram pelayanan publik sesuai engan kebutuhan dan aspirasi masyarakat. Responsivitas yang rendah ditunjukkan dengan ketidakselarasan antara pelayanan dengan kebutuhan masyarakat. Hal tersebut jelas menunjukkan kegagalan organisasi dalam mewujudkan misi dan tujuan organisasi publik. Organisasi yang memiliki responsivitas rendah dengan sendirinya memiliki kinerja yang jelek pula.

d. Responsibilitas

Responsibilitas menjelaskan apakah pelaksanaan kegiatan organisasi publik itu dilakukan sesuai dengan prinsip-prinsip administrasi yang benar atau sesuai dengan kebijakan organisasi, baik yang eksplisit maupun implisit. Oleh sebab itu, responsibilitas bisa saja pada suatu ketika berbenturan dengan responsivitas.

e. Akuntabilitas

Akuntabilitas Publik menunjuk pada seberapa besar kebijakan dan kegiatan organisasi publik tunduk pada para pejabat public yang dipilih oleh rakyat. Asumsinya adalah bahwa para pejabat politik tersebut karena dipilih oleh rakyat, dengan sendirinya akan selalu merepresentasikan kepentingan rakyat. Suatu kegiatan organisasi public memiliki akuntabilitas yang tinggi kalau kegiatan itu dianggap benar dan sesuai dengan nilai dan 
norma yang berkembang dalam masyarakat.

Penilaian kinerja aparatur pemerintah dapat dilakukan eksternal yaitu melalui respon kepuasan masyarakat. Pemerintah menyusun alat ukur untuk mengukur kinerja pelayanan publik secara eksternal melalui keputusan Menpan No. 25/KEP/M.PAN/2/2004 tentang pedoman penyusunan indeks kepuasan masyarakat unit pelayanan instansi pemerintah, terdapat 14 indikator kriteria pengukuran kinerja organisasi sebagai berikut :

1. Prosedur pelayanan, yaitu kemudahan tahapan pelayanan yang diberikan kepada masyarakat dilihat dari sisi kesederhanaan alur pelayanan.

2. Persyaratan pelayanan, yaitu persyaratan teknis dan administratif yang diperlukan untuk mendapatkan pelayanan sesuai dengan jenis pelayanannya.

3. Kejelasan petugas pelayanan, yaitu keberadaan dan kepastian petugas yang memberikan pelayanan (nama, jabatan serta kewenangan dan tanggung jawabnya).

4. Kedisiplinan petugas pelayanan, yaitu kesungguhan petugas dalam memberikan pelayanan terutama terhadap konsistensi waktu kerja sesuai ketentuan yang berlaku.
5. Tanggung jawab petugas pelayanan, yaitu kejelasan wewenang dan tanggung jawab petugas dalam penyelenggaraan dan penyelesaian pelayanan.

6. Kemampuan petugas pelayanan, yaitu tingkat keahlian dan keterampilan yang dimiliki petugas dalam memberikan atau menyelesaikan pelayanan kepada masyarakat.

7. Kecepatan pelayanan, yaitu target waktu pelayanan dapat diselesaikan dalam waktu yang telah ditentukan oleh unit penyelenggara pelayanan.

8. Keadilan mendapatkan pelayanan, yaitu pelaksanaan pelayanan dengan tidak membedakan golongan atau status masyarakat yang dilayani.

9. Kesopanan dan keramahan petugas, yaitu sikap dan perilaku petugas dalam memberikan pelayanan kepada masyarakat secara sopan dan ramah serta saling menghargai dan menghormati.

10. Kewajaran biaya pelayanan, yaitu keterjangkauan masyarakat terhadap besarnya biaya yang ditetapkan oleh unit pelayanan.

11. Kepastian biaya pelayanan, yaitu kesesuaian antara biaya yang dibayarkan dengan biaya yang ditetapkan. 
12. Kepastian jadwal pelayanan, yaitu pelaksanaan waktu pelayanan sesuai dengan ketentuan yang telah ditetapkan.

13. Kenyamanan lingkungan, yaitu kondisi sarana dan prasarana pelayanan yang bersih, rapih dan teratur sehingga dapat memberikan rasa nyaman kepada penerima pelayanan.

14. Keamanan pelayanan, yaitu terjaminnya tingkat keamanan lingkungan unit penyelenggara pelayanan ataupun sarana yang digunakan sehingga masyarakat merasa tenang untuk mendapatkan pelayanan terhadap resiko-resiko yang diakibatkan dari pelaksanaan pelayanan.

Berdasarkan pada uraian di atas, pengukuran kinerja organisasi publik dapat dilakukan secara internal dan eksternal. Penilaian secara internal adalah mengetahui apakah proses pencapaian tujuan sudah sesuai dengan rencana bila dilihat dari proses dan waktu, sedangkan penilaian keluar (eksternal) dilakukan dengan mengukur kepuasan masyarakat terhadap pelayanan yang diberikan oleh organisasi.

Bagi organisasi, kinerja yang efektif berarti output tetap dipertahankan meskipun jumlah pekerjaannya sedikit, atau produktivitasnya ditambah. Perlu ditekankan bahwa keefektifan kinerja seseorang tergantung pada organisasi itu sendiri, apakah mempunyai kejelasan misi, strategi dan tujuan.

Setiap pegawai yang diberikan tugas diharapkan mampu menunjukan kinerja yang baik dan memberikan kontribusi yang maksimum terhadap pencapaian tujuan organisasi. Kinerja itu dapat dartikan sebagai hasil kerja atau kemampuan kerja yang diperlihatkan seseorang atau kelompok atau suatu pekerjaan pada waktu tertentu. Kinerja itu dapat berupa produk akhir dari ( barang dan jasa )yang berbentuk perilaku, kecakapan, kompetensi, sarana, prasarana, ketrampilan khusus yang dapat mendukung pencapaian tujuan dan sasaran organisasi.

\section{Konsep Pelayanan}

Menurut petugas pelayanan, lamanya pemberian pelayanan kepada masyarakat pengguna jasa disebabkan adanya kendala internal dan eksternal. Kendala internal meliputi peralatan pendukung yang tidak memadai, kualitas SDM rendah dan koordinasi antar unit. Sarana dan prasarana yang tidak memadai yang dimiliki oleh instansi sering menghambat pemberian pelayanan kepada pengguna jasa. Selain itu, faktor kualitas SDM yang relatif rendah semakin menghambat pemberian pelayanan kepada 
masyarakat. Kualitas SDM yang rendah tersebut ditandai dengan ketidakmampuan petugas memberikan solusi kepada pelanggan.

Pelayanan merupakan salah satu ujung tombak dari upaya pemuasan pelanggan dan sudah merupakan keharusan yang wajib dioptimalkan baik oleh individu maupun organisasi, karena dari bentuk pelayanan yang diberikan tercermin kualitas individu atau organisasi yang memberikan pelayanan.

Karisma dalam Kamus Bahasa Indonesia (1997:571) Istilah pelayanan berasal dari kata "layan" yang artinya membantu menyiapkan atau mengurus segala apa yang diperlukan orang lain untuk perbuatan melayani. Dalam kamus besar Bahasa Indonesia, kata pelayanan diartikan sebagai berikut :

1. Perihal cara melayani

2. Servis jasa

3. Kemudahan yang diberikan sehubungan dengan jual beli barang/jasa.

Dalam artian in, maka pelayanan jika dihubungkan dengan administrasi publik dapat definisikan sebagai kualitas pelayanan birokrat kepada masyarakat.

Sianipar (1998:4) mengemukakan pengertian pelayanan sebagai Cara melayani, menyiapkan atau menjamin keperluan seseorang atau kelompok orang. Melayani adalah meladeni atau membantu mengurus keperluan atau kebutuhan seseorang sejak diajukan permintaan sampai penyampaian atau penyerahannya. Sementara itu, menurut The Liang Gie (1997:23) yang mendefinisikan pelayanan bagi masyarakat atau kegiatan dari organisasi yang dilakukan untuk mengamalkan dan mengabdikan diri kepada masyarakat.

Dari beberapa pengertian di atas maka dapat disimpulkan bahwa Pelayanan adalah cara melayani, membantu menyiapkan, mengurus, menyelesaikan keperluan, kebutuhan seseorang atau sekelompok orang. Artinya objek yang dilayani adalah masyarakat yang terdiri dari individu, golongan, dan organisasi (sekelompok organisasi).

Keputusan Menteri Negara Pendayagunaan Aparatur Negara Nomor 81 Tahun 1993 tentang Pedoman Tata Laksana Pelayanan adalahSegala bentuk pelayanan umum yang dilaksanakan oleh Instansi Pemerintah di pusat, di daerah, dan di lingkungan Badan Usaha Milik Negara atau Daerah dalam bentuk barang dan jasa, baik dalam rangka upaya pemenuhan pelaksanaan ketentuan peraturan perundang-undangan.

Sementara itu sehubungan dengan konsep pelayanan Publik, Sinambela (2008:5) memberikan pengertian bahwa Pelayanan Publik dipahami sebagai setiap kegiatan yang dilakukan oleh pemerintah 
terhadap sejumlah manusia yang memiliki setiap kegiatan yang menguntungkan dalam suatu kumpulan atau kesatuan, dan menawarkan kepuasan meskipun hasilnya tidak terikat pda suatu produk secara fisik.

Menurut Undang-undang nomor 25 Tahun 2009 tentang Pelayanan Publik, mengatakan bahwa yang dimaksud dengan pelayanan publik adalah Kegiatan atau ragkaian kegiatan dalam rangka pemenuhan kebuthan pelayanan sesuai dengan peraturan perundang-undangan bagi setiapa warga Negara dan penduduk atas barang, jasa dan/atau pelayanan administratif yang disediakan oleh penyelenggara pelayanan publik.

Untuk dapat memberikan pelayanan yang memuaskan bagi pengguna jasa, penyelenggaraan pelayanan harus memenuhi asas-asas pelayanan. Berdasarkan Keputusan Menpan Nomor 63 Tahun 2004 yang menyatakan asasasas pelayanan sebagai berikut :

1. Transparansi

Bersifat terbuka, mudah dan dapat diakses oleh semua pihak yang membutuhkan dan disediakan secara memadai serta mudah dimengerti.

1. Akuntabilitas

Dapat dipertanggungjawabkan sesuai dengan ketentuan peraturan perundang-undangan.

2. Kondisional
Sesuai dengan kondisi dan kemampuan pemberi dan penerima pelayanan dengan tetap berpegang pada efisiensi dan efektifitas.

\section{Partisipatif}

Mendorong peran serta masyarakat dalam penyelenggaraan pelayanan publik dengan memperhatikan aspirasi, kebutuhan dan harapan masyarakat.

5. Kesamaan hak

Tidak diskriminatif dalam arti tidak membedakan suku, ras, agama, gender, dan status ekonomi.

6. Keseimbangan hak dan kewajiban

Pemberi dan penerima pelayanan publik harus memenuhi hak dan kewajiban masing-masing pihak.

Berdasarkan pengertian di atas, maka pelayanan bagi instansi atau lembaga pemerintah, khususnya yang bergerak dalam bidang pelayanan jasa, maka sudah merupakan kewajiban setiap aparat atau karyawannya memberikan pelayanan terbaik. Suatu instansi atau lembaga dalam operasioanalnya tidak terlepas dari penilaian atau respon masyarakat (konsumen) maupun posisinya sebagai mitra dalam hal mewujudkan efektivitas pelayanan.

Bagi institusi pemerintah yang berorientasi pada pelayanan publik prinsipnya mengacu pada pola pelayanan umum yang sama. Pola pelayanan yang 
dimaksud adalah Pedoman Tata Laksana Pelayanan Umum berdasarkan surat keputusan Menteri Pendayagunaan Aparatur Negara tersebut tercantum bahwa, Segala bentuk kegiatan pelayanan umum yang dilaksanakan oleh instansi pemerintah di pusat, di daerah, dan di Lingkungan Badan Usaha Milik Negara atau Daerah dalam bentuk barang dan jasa, baik dalam rangka upaya pemenuhan pelaksanaan ketentuan peraturan perundang-undangan.

\section{METODOLOGI PENELITIAN}

Metode yang digunakan dalam penelitian ini adalah metode Kuantitatif asosiatif yakni mencari hubungan antara variabel yang satu dengan variabel yang lain (Sugiono 2009:11). Dengan Lokus Penelitian pada Desa Meyano Bab Kecamatan Kormomolin Kabupaten Kepulauan Tanimbar.

Sampel yang digunakan dalam penelitian ini sebanyak 50 responden yang merupakan jumlah minimum ang diperlukan untuk melakukan penelitian dari jumlah populasi sebanyak 844 jiwa orang yang diambil dengan menggunakan teknik purposive sampling dan selanjutnya data dikumpulakan dengan menggunakan kusioner yang berupa daftar pertanyaan berupa multiple choice dengan skala likert, observasi, wawancara dengan kepustakaan.

Data yang berhasil dikumpulkan dalam penelitian ini akan dianalisa dengan menggunakan alat analaisa statistik Korelasi Pearson Pruduck Moment yaitu :

$$
\mathrm{r}_{\mathrm{xy}}=\frac{n\left(\sum X Y\right)-\left(\sum X\right) \cdot\left(\sum Y\right)}{\sqrt{\left\{n \sum X^{2}-\left(\sum X\right)^{2}\right\}\left\{n \sum Y^{2}-\left(\sum Y\right)^{2}\right\}}}
$$

Dimana:

$$
\begin{aligned}
& r=\text { Koefisien Korelasi } \\
& X=\text { Nilai atau Skor }
\end{aligned}
$$

Variabel Bebas

$\mathrm{Y}=$ Nilai atau Skor Terikat

$\mathrm{n}=$ Jumlah Sampel

Sedangkan arti harga $\mathrm{r}$ akan dikonsultasikan dengan nilai interpretasi pada tabel Koefisien Korelasi sebagai berikut :

\begin{tabular}{|c|l|}
\hline Interval Koefisien & \multicolumn{1}{c|}{ Tingkat Hubungan } \\
\hline $0,80-1,000$ & Sangat kuat \\
\hline $0,60-0,799$ & Kuat \\
\hline $0,40-0,599$ & Cukup kuat \\
\hline $0,20-0,399$ & Rendah \\
\hline $0,00-0,199$ & Sangat rendah \\
\hline
\end{tabular}

Selanjutnya untuk menyatakan besar kecilnya sumbangan Varibel X terhadap Variabel Y dapat ditentukan dengan rumus Koefisien Determinan sebagai berikut :

$$
K P=r^{2} \times 100 \%
$$


Untuk menguji kebenaran hipotesa penelitian, akan di uji signifikasinya dengan rumus uji $\mathrm{t}(t$-test $)$ pada taraf nyata $5 \%(0,05)$ uji dua arah dengan $\mathrm{dk}=\mathrm{n}-2$ dengan formula sebagai berikut :

$$
t_{\text {hitung }}=\frac{r \sqrt{n-2}}{\sqrt{1-r^{2}}}
$$

Kaidah Pengujian :

Jika Jika $t_{\text {hitung }} \geq t_{\text {tabel}}$, maka signifikan

\section{PEMBAHASAN}

Berdasarkan hasil perhitungan yang dilakukan dengan analaisa statistik Korelasi Pearson Pruduck Moment menunjukan bahwa nilai korelasi $r$ yang berhasil diperoleh sebesar 0,82. Nilai tersebut mengandung arti bahwa kedua variabel pokok dalam penelitian ini mempunyai hubungan yang Sangat Kuat . Hal ini menunjukan bahwah Variabel Kinerja Pemerintah mempunyai hubungan yang signifikan dengan Pelayanan Kepada Masyarakat di Meyano Bab, Kecamatan Kormomolin Kabupaten Kepulaluan Tanimbar yang dapat diuraikan sebagai berikut :

\section{Kinerja Aparatur Pemerintah Desa}

Kineja Aaparatur Pemerintah Desa adalah capaian atau prestasi kerja yang dihasilkan oleh aparatur pemerintah desa secara makasimal untuk mewujudkan tujuan organisasi. Adapun variable ini diukur dengan menggunakan lima indikator yang dapat sebagai berikut :

1. Prosedur pelayanan, pada indikator penelitian in terdapat 24 orang responden atau $48 \%$ yang menjawab sangat setuju bahwa selama ini prosedur atau alur pelayanan aparat pemerintah desa Meyano Bab mudah, sederhana / tidak berbelit-belit, 5 orang responden atau $10 \%$ tidak setuju bahwa prosedur atau alur pelayanan aparat pemerintah desa Meyano Bab mudah, sederhana / tidak berbelit-belit, sedangkan 21 orang responden atau $42,00 \%$ sangat tidak setuju bahwa prosedur atau alur pelayant aparat pemerintah desa Meyano Bab mudah, sederhana.

2. Tanggungjawab petugas, pada indikator ini terdapat 25 orang responden atau 50\% menjawab sangat setuju mengatakan bahwa selama ini pelayanan yang dilakukan oleh aparatur pemerintah desa Meyano bab dapat dipertanggungjawabkan, sedangkan 12 Orang atau 24\% tidak setuju mengatakan bahwa selama ini pelayanan yang dilakukan oleh aparatur pemerintah desa Meyano bab dapat dipertanggungjawabkan, 
sedangkan 13 orang atau $26 \%$ sangat tidak setuju mengatakan bahwa pelayanan yang dilakukan oleh aparatur pemerintah desa Meyano bab selama ini dapat dipertanggungjawabkan

3. Kecepatan Pelayanan, inikator ini untuk mengukur pelayanan aparatur pemerintah desa diperoleh data bahwa terdapat 25 orang responden atau 50\% menanggapi sangat setuju bahwa selama ini pelayanan yang dilakukan oleh aparat pemerintah desa diselesaikan dalam waktu yang cepat atau dalam waktu yang ditentukan, 3 orang tidak setuju bahwa selama ini pelayanan yang dilkukan oleh aparat pemerintah desa diselesaikan dalam waktu yang cepat atau waktu yang ditentukan sedangkan 22 orang atau $44 \%$ sangat tidak setuju bahwa selama ini pelayanan yang dilkukan oleh aparat pemerintah desa diselesaikan dalam waktu yang cepat atau waktu yang ditentukan

4. Keadilan Mendapatkan Pelayanan, Pertanyaan ke empat variabel penelitian kinerja aparatur pemerintah desa, diperoleh data bahwa terdapat 26 orang responden atau $52 \%$ sangat setuju bahwa selama ini pelayanan yang diberikan oleh aparat desa tidak membeda-bedakan golongan atau status sosial masyarakat, terdapat 5 Orang atau $10 \%$ tidak setuju bahwa pelayanan yang diberikan oleh aparat desa tidak membedabedakan golongan atau status sosial masyarakat dan 19 Orang atau 38\% sangat tidak setuju bahwa selama ini pelayanan yang diberikan oleh aparat desa membeda-bedakan golongan atau status sosial masyarakat.

5. Persyaratan pelayanan, sedangkan pada terakhir ini diperoleh data bahwa terdapat 19 orang atau $38 \%$ sangat setuju bahwa selama ini Persyaratan Teknis dan Administrasi yang diperlukan untuk pelayanan sesuai dengan pelayanannya / tidak terlalu banyak sehingga memberatkan, 9 orang atau $18 \%$ tidak setuju bahwa selama ini Persyaratan Teknis dan Administrasi yang diperlukan untuk pelayanan sesuai dengan pelayanannya / tidak terlalu banyak sehingga memberatkan dan 22 orang atau $44 \%$ sangat tidak setuju bahwa selama Persyaratan Teknis dan Administrasi yang diperlukan untuk pelayanan sesuai 
dengan pelayanannya / terlalu banyak sehingga memberatkan.

\section{Pelayanan Kepada Masyarakat}

Pelayanan kepada masyarakat merupakan sebuh bentuk pengabdian diri dari aparatur pemerintah desa untuk memnuhi tuntutan dan kebutuhan masyarakat secara sepat dan adil. Adapun variable ini diukur dengan menggunakan indikator-indikator sebagai berikut :

1. Kondisional, pada indikator ini terdapat 23 orang responden atau $46 \%$ mengatakan sangat setuju bahwa selama ini Pelayanan yang diberikan Aparat Desa sesuai dengan kondisi atau kemampuan masyarakat, hemat waktu, biaya dan tenaga, sedangkan 9 Orang atau $18 \%$ mengatakan tidak setuju bahwa selama ini Pelayanan yang diberikan Aparat Desa sesuai dengan kondisi atau kemampuan masyarakat, hemat waktu, biaya dan tenaga, sedangkan 18 orang atau $36 \%$ mengatakan sangat tidak setuju bahwa selama ini Pelayanan yang diberikan Aparat Desa sesuai dengan kondisi atau kemampuan masyarakat,hemat waktu, biaya dan tenaga.

2. Akuntabilitas, indikator ini menunjukan bahwa ada 33 orang responden atau $66 \%$ sangat setuju mengatakan bahwa selama ini
Pelayanan yang diberikan Aparat Desa dapat dipertanggungjawabkan sesuai ketentuan peraturan perundang-undangan yang berlaku, 2 orang atau $4 \%$ mengatakan tidak setuju bahwa selama ini Pelayanan yang diberikan Aparat Desa dapat dipertanggungjawabkan sesuai ketentuan peraturan perundangundangan yang berlaku sedangkan 15 orng atau $30 \%$ mengatakan sangat tidak setuju bahwa selama ini Pelayanan yang diberikan Aparat Desa dapat dipertanggungjawabkan sesuai ketentuan peraturan perundang-undangan yang berlaku.

3. Partisipatif, Sementara itu pada indikator ke tiga variabel pelayanan, menunjukan bahwa terdapat 25 orang responden atau 50\% mengatakan sangat setuju bahwa selama ini Pelayanan yang diberikan Aparat Desa memperhatikan aspirasi, kebutuhan dan harapan masyarakat, 5 orang atau $10 \%$ mengatakan tidak setuju bahwa selama ini Pelayanan yang diberikan Aparat Desa memperhatikan aspirasi, kebutuhan dan harapan masyarakat sedangkan 16 orang atau $32 \%$ mengatakan mengatakan sangat tidak setuju bahwa selama ini Pelayanan yang diberikan Aparat Desa 
memperhatikan aspirasi, kebutuhan dan harapan masyarakat

4. Kesamaan Hak, Selanjutnya inikator ini menunjukan data bahwa terdapat 29 orang atau $58 \%$ responden mengatakan sangat setuju bahwa pelayanan yang diberikan Aparat Desa tidak diskriminatif dalam arti tidak membedakan jenis kelamin, status ekonomi, atau status sosial dalam masyarakat, 5 orang atau $10 \%$ mengatakan tidak setuju bahwa pelayanan yang diberikan Aparat Desa tidak diskriminatif dalam arti tidak membedakan jenis kelamin, status ekonomi, atau status sosial dalam masyarakat sedangkan 16 orang atau $32 \%$ orang sangat tidak setuju bahwa Pelayanan yang diberikan Aparat Desa diskriminatif dalam arti membedakan jenis kelamin, status ekonomi, atau status sosial dalam masyarakat.

5. Transparan, sedangkan pada terakhir variabel penelitian ini menjelaskan bahwa terdapat 30 orang responden atau $60 \%$ mengatakan sangat setuju bahwa selama ini pelayanan yang diberikan oleh Aparat Desa bersifat terbuka, mudah dan dapat diakses oleh semua masyarakat yang membutuhkan dan disediakan secara memadai serta mudah dimengerti, 5 Orang atau $10 \%$ tidak setuju bahwa selama ini yang diberikan oleh Aparat Desa bersifat terbuka, mudah dan dapat diakses oleh semua masyarakat yang membutuhkan dan disediakan secara memadai serta mudah dimengerti sedangkan 15 orang atau $30 \%$ sangat tidak setuju bahwa selama ini pelayanan yang diberikan oleh Aparat Desa bersifat terbuka, mudah dan dapat diakses oleh semua masyarakat yang membutuhkan dan disediakan secara memadai serta mudah dimengerti.

\section{Kinerja Aparatur Pemerintah Desa Terhadap Pelayanan Kepada Masyarakat}

Kinerja Aparatur Pemerintah Desa merupakan rangkaian aktivitas untuk merencanakan, mengorganisasikan, mengarahkan, mengawasi, dan mengendalikan, hingga menyelenggarakan secara tertib pekerjaan administrasi perkantoran dalam menunjang pencapaian tujuan organisasi. Tujuan organisa yang dimaksudkan dalam hal ini adalah untuk memberikan pelayanan kepada kepada masyarakat adil taranparan efektif dan efisien.

Untuk mengetahui hubungan antara Kinerja Aparatur Pemerintah Desa dengan Peyananan Kepada Masyarakat maka dianalisis dengan menggunakan rumus Korelasi Pearson Produk, dimana 
langka pertama yang dilakukan adalan membuat sebuah tabel penolong untuk perhitungan korelasinya yang memuat total keseluruhan jawaban responden atas variabel X (Kinerja Aparatur Pemerintah Desa) dan variabel Y (Peyananan Kepada Masyarakat) dimana di peroleh nilainilanya sebagai berikut :

$$
\begin{aligned}
& \sum \mathrm{X}=672, \quad \sum \mathrm{Y}=824, \quad \sum \mathrm{X}^{2}=13809 \\
& \sum \mathrm{Y}^{2}=12325, \quad \sum \mathrm{XY}=16956, \quad \mathrm{n}=50
\end{aligned}
$$

Dengan data nilai yang telah diperoleh tersebut diatas, kemudian selamjutnya akan dianalisis dengan menggunakan rumus Korelasi Pearson Produk Moment maka diperoleh nilai Koefisien Korelasi (r) sebesar 0.82 yang jika dikonsultasiskan pada tabel interval koefisien berada pada posisi $0,80-1,000$ variabel X (Kinerja Aparatur Pemerintah Desa) dan variabel Y (Peyananan Kepada Masyarakat) memiliki hubungan yang Sangat Kuat.

Untuk mencari besar sumbangan (Kontribusi) variabel Kinerja Aparatur Pemerintah Desa terhadap variabel Peyananan Kepada Masyarakat, maka digunakan rumus koefisien determinasi (Kd) dimana $\mathrm{Kd}=r^{2} \times 100 \%$, maka diperoleh nilai $\mathrm{Kd}$ sebesar $67 \%$. Hal ini menunjukan bahwa variabel Kinerja Aparatur Pemerintah Desa memberikan kontribusi sebesar $67 \%$ terhadap variabel
Peyananan Kepada Masyarakat, sedangkan sisanya $33 \%$ ditentukan oleh faktor lain yang tidak sempat diteliti.

Selanjutnya dari nilai korelasi yang telah dieroleh tersebut, maka dilakukan uji signifikansi dengan mengunakan formula uji t (t-test) pada taraf nyata signifikan 5\% $(0,05)$ uji dua arah dengan dk = n-2 (50$2=48$ ). Diperoleh nilai t-hitung sebesar 9,95 yang jika dikonsultasikan dengan nilai t-tabel pada taraf signifikan 5\% $(0,05) \mathrm{dk}=48(1,684)$ maka diperoleh nilai t-hitung sebesar 9,95 lebih besar dari nilai t-tabel 1,98 $(9,95>1,684)$, sehingga dapat dikatakan bahwa hipotesa Ha diterima sedangkan hipotesa $\mathrm{H}_{0}$ ditolak. Dengan demikian hipotesa yang diajukan terbukti/teruji kebenarannya yaitu terdapat hubungan yang sangat kuat antara variabel bebas Kinerja Aparatur Pemerintah Desa dengan Peyananan Kepada Masyarakat di Desa Meyano Bab Kecamatan Tanimbar Kormomolin Kabupaten Kepulauan Tanimbar.

\section{Kesimpulan}

Berdasarkan Hasil Analisa koefisien Korelasi product momentHasil perhitungan dengan analisa koefisien korelasi menunjukan bahwa nilai korelasi r yang berhasil diperoleh sebesar 0,82 Nilai tersebut mengandung arti bahwa 
kedua variabel pokok dalam penelitian ini mempunyai hubungan yang sangat kuat.

Berdasarkan Hasil Analisa Uji t, hasil pengolahan data diperoleh $\mathrm{t}$ hitung $=$ 9,95 sedangkan $\mathrm{t}$ tabel dengan taraf nyata $5 \%$ dan degree of freedom (df) jumlah sampel $\mathrm{n}=50$ df penyebut $\mathrm{n}-2=50-2=$ 48. Maka nilai t. tabel dari df 0.05 $(48=1,684)$. Atas dasar perhitungan analisis koefisien korelasi nilai t hitung untuk variabel Kinerja adalah 9,95. Karena $\mathrm{t}$ hitung lebih besar dari t tabel, yaitu 9,95> 1,684, maka Ho ditolak dan $\mathrm{Ha}$ diterima. Sehingga dari hasil uji statistic tersebut menunjukan bahwa Ada Hubungan antara Kinerja ( $\mathrm{X}$ ) dengan Pelayanan (Y) pada taraf nyata 5\%

\section{Saran}

Peningkatan Kinerja Pelayanan Aparatur Pemerintah Desa di Meyano Bab Kecamatan Kormomolin dapat dilakukan dengan cara :

a. Menyederhanakan Prosedur atau Alur Pelayanan

b. Menyelesaikan pelayanan dalam waktu cepat, atau waktu yang ditentukan

c. Tidak membeda-bedakan golongan atau status sosial masyarakat

d. Pelayanan yang diberikan aparat desa sesuai dengan kondisi atau kemampuan masyarakat, hemat waktu dan biaya.

e. Pelayanan yang diberikan aparat desa memperhatikan aspirasi, kebutuhan dan harapan masyarakat. 


\section{DAFTAR PUSTAKA}

Arikunto, Suharsimi, 2002. Prosedur Penelitian Edisi Revisi V. Jakarta : PT Rineka Cipta.

Alaslan, Amtai. 2021. Formulasi Kebijakan Publik: Studi Relokasi Pasar. Banyumas: CV. Pena Persada

Ghozali, Imam, 2005, Aplikasi Analisis Multivariate dengan Program SPSS. Semarang : Badan Penerbit Universitas Diponegoro

Kurniawan, 2005, Tranformasi Pelayanan Publik. Jogjakarta PEMBARUAN

Moenir, 2006, Manajemen Pelayanan umum, Jakarta : Bumi Aksara

Siagian Sondang P, 1982, Peranan Staf dalam Management, Jakarta :Gunung Agung

Siagian Sondang P, 1988, Organisasi Kepemimpinan dan Perilaku Administrasi, Jakarta : Gunung Agung

Sukarna, 1990, Administrasi

Kepegawaian, Bandung : Mandar Maju.

Sukirno et al 2004. Balanced Scorecard Sebagai Alat Pengukuran Kinerja Manajemen. Jurnal Pendidikan Akuntansi Indonesia Vol. III No. $1: 40-50$

Kepuasan Masyarakat Unit Pelayanan Instansi Pemerintah,
Sukarna, $\quad 1990, \quad$ Administrasi Kepegawaian, Bandung : Mandar Maju

Teori Online, Kinerja https://teorionline word press.com 2008/6/10, diakses pada tanggal 02 April 2015

Teori Online, Kinerja https://intanghina word press.com 2008/6/10, diakses pada tanggal 02 April 2015

\section{REFERENSI LAIN :}

Alaslan, Amtai (2021). Analilis Nilai-nilai Budaya Duan Lolat Berbasis Kearifan Lokal Pada Masyarakat Tanimbar di Kabupaten Maluku Tenggara Barat. OTONOMI Jurnal Ilmu Administrasi Vol. 11. No. 22

Undang-undang nomor 25 Tahun 2009 tentang Pelayanan Publik.

Undang-undang nomor 23 Tahun 2016 tentang Pemerintahan Daerah.

Keputusan Menpan Nomor 63 Tahun 2004 Tentang Pelayanan Publik

Keputusan Menpan No. 25/KEP/M.PAN/2/2004. Tentang Pedoman Penyusunan Indeks Kepuasan Masyarakat Unit Pelayanan Instansi Pemerintah,

Keputusan Menpan No. 25/KEP/M.PAN/2/2004. Tentang Pedoman Penyusunan Indeks 